\title{
Regional consensus opinion for the management of Beta thalassemia major in the Arabian Gulf area
}

\author{
Mohamad H Qari ${ }^{1}$, Yasser Wali ${ }^{2}$, Muneer H Albagshi ${ }^{3}$, Mohammad Alshahrani ${ }^{4}$, Azzah Alzahranii ${ }^{4}$, Ibrahim A Alhijji ${ }^{5}$, \\ Abdulkareem Almomen ${ }^{6}$, Abdullah Aljefri ${ }^{7}$, Hussain $\mathrm{H} \mathrm{Al} \mathrm{Saeed}^{8}$, Shaker Abdullah ${ }^{9}$, Ahmad Al Rustumani ${ }^{10}$, \\ Khoutir Mahour ${ }^{11}$ and Shaker A Mousa ${ }^{12^{*}}$
}

\begin{abstract}
Thalassemia syndrome has diverse clinical presentations and a global spread that has far exceeded the classical Mediterranean basin where the mutations arose. The mutations that give rise to either alpha or beta thalassemia are numerous, resulting in a wide spectrum of clinical severity ranging from carrier state to life-threatening, inherited hemolytic anemia that requires regular blood transfusion. Beta thalassemia major constitutes a remarkable challenge to health care providers. The complications arising due to the anemia, transfusional iron overload, as well as other therapy-related complications add to the complexity of this condition. To produce this consensus opinion manuscript, a PubMed search was performed to gather evidence-based original articles, review articles, as well as published work reflecting the experience of physicians and scientists in the Arabian Gulf region in an effort to standardize the management protocol.
\end{abstract}

Keywords: Anemia, Chelation, Arabian Gulf, Iron chelation therapy, Iron overload, Thalassemia management, Transfusion

\section{Introduction}

Thalassemia is a group of inherited disorders that arise as a result of certain mutations in hemoglobin $(\mathrm{Hb})$ genes, affecting the makeup of $\mathrm{Hb}$ in the red blood cells, which leads to certain pathophysiological disorders [1]. The genetic disorder is characterized by the absolute or partial synthesis of one or more alpha $(\alpha)$ - or beta $(\beta)$ globin chains $[2,3]$. The types of $\beta$-thalassemia are called major, intermedia, and minor. $\beta$-Thalassemia major is caused by a defect in 2 genes that leads to absence or a severe decrease in $\beta$-globin synthesis. $\beta$-Thalassemia intermedia is a clinical phenotype with moderate anemia and transfusion independence. Genetically it results from mutations in the $2 \beta$ genes resulting in mild to moderate decrease in their synthesis. $\beta$-Thalassemia minor, or thalassemia trait, occurs when the defect is present in only 1 gene [2].

\footnotetext{
* Correspondence: shaker.mousa@acphs.edu

${ }^{12}$ The Pharmaceutical Research Institute at Albany College of Pharmacy and Health Sciences, Rensselaer, New York, USA

Full list of author information is available at the end of the article
}

$\beta$-Thalassemia carriers comprise $1.5 \%$ of the worldwide population, with an estimated 60,000 infants with a serious defect being born every year [1]. In the United States, approximately 1,000 individuals have $\beta$ thalassemia major, the most severe form of thalassemia [4]. It is most commonly found in people of Mediterranean descent, such as Italians and Greeks, but also affects people from other parts of the world such as Africa, the Middle East, the Indian subcontinent, and Southeast Asia [2,5].

Blood transfusions are often required to treat patients with thalassemia major, who are transfusion-dependent and frequently need to receive 2 to 4 units per month of packed red blood cells [6]. Patients with $\beta$-thalassemia major require transfusions throughout life to achieve the target $\mathrm{Hb}$ level in the range 9 to $10 \mathrm{~g} / \mathrm{dL}$ and to promote normal growth $[7,8]$. Iron overload can develop in transfusion-dependent patients as a result of nonremoval of excess iron. High iron concentration load can cause complications due to iron deposition in organs such as the heart, liver, and endocrine glands. 


\section{Epidemiology}

Thalassemia is the most common form of inherited anemia worldwide [9]. It occurs with a high frequency in a broad belt extending from the Mediterranean basin through to the Middle East, Indian subcontinent, and Southeast Asia [10]. Thalassemia is a growing global health problem due to extensive population migrations. About 3\% of the world population (about 200 million people) are carriers of the $\beta$-thalassemia gene [11].

The incidence of $\beta$-thalassemia in Arabian Gulf countries is not clearly known due to lack of mandatory screening programs [12-16]. The majority of data were obtained from scattered screening studies using $\mathrm{Hb}$ electrophoresis as summarized in Table 1.

\section{Pathophysiology}

$\beta$-Thalassemia is a group of heterogeneous autosomal recessive disorders arising due to the absence or reduced synthesis of the $\beta$-globin chain [18]. $\beta$-Thalassemia could be associated with severe congenital disorders caused by mutations in the $\beta$-globin gene resulting in the absence or reduced synthesis of the $\beta$-globin chain $[1,12]$. This deficit of $\beta$-globin chains leads to precipitation of excess $\alpha$-globin chains resulting in the formation of inclusion bodies, which contribute to hemolysis of red blood cells. Hematological changes are manifested between the ages of 3 months and 6 months onwards [13]. Over 200 different mutations have been elucidated worldwide, and the mutations are population-specific. In the Middle East, codon 39 (C > T), IVSI-110 (G > A), IVSI-1 (G > A), IVSI-6 $(\mathrm{T}>\mathrm{C})$, IVSII-1 $(\mathrm{G}>\mathrm{A})$, codon 5(-CT), and IVSI-5 $(\mathrm{G}>\mathrm{C})$ mutations account for more than $90 \%$ of $\beta$-thalassemia mutations in the region. However, these mutations differ in numbers and frequencies between different populations of the Middle East. Over 50 different mutations have been identified in the Arab populations, reflecting the heterogeneity of these populations $[19,20]$. The molecular spectrum of $\beta$-thalassemia in the Arab populations of Jordan, Egypt, Syrian Arab Republic, Lebanon, Yemen, and Saudi Arabia revealed that the most frequent mutations were: IVS-1-5 (G-C), IVS-II-1 (G-A), IVS-1-1, Fr 8/9, Fr 41/42, Cd 15, Cd 16, Cap +1

Table 1 Estimated prevalence of $\boldsymbol{\beta}$-thalassemia (minor and major) in Arabian Gulf countries

\begin{tabular}{llll}
\hline Country & Minor (\%) & Major (\%) & Reference \\
\hline Saudi Arabia & 3.4 & $\mathrm{NA}^{*}$ & {$[12]$} \\
Bahrain & 0.88 & 0.16 & {$[13]$} \\
Qatar & 28 & 0.07 & {$[14]$} \\
United Arab Emirates & 1.7 & $\mathrm{NA}^{*}$ & {$[15]$} \\
Oman & 2 & 0.04 & {$[16,17]$} \\
\hline
\end{tabular}

* Not available.
(A-C), IVS-1-110, IVS-1-3' end (-25 bp) and IVS-1-6 [21-23].

\section{Presentation and diagnosis}

$\beta$-Thalassemia comprises a complex spectrum of clinical presentations. The clinical phenotype is influenced by the genetic phenotype and other modifiers. The basic disease is caused by the inability to produce normal $\beta$ globin chain with the consequence of excess $\alpha$-chain, leading to disruption of the $\alpha: \beta$ ratio, which in turn will cause various cellular and clinical syndromes [1,24].

$\beta$-Thalassemia is clinically classified into 4 subtypes (Table 2):

1. $\beta$-thalassemia silent carriers; asymptomatic, one $\beta$ globin chain is normal and the other is partially defective $\left(\beta \beta^{+}\right)$.

2. $\beta$-thalassemia trait; one $\beta$-chain is totally defective and the other is normal $\left(\beta \beta^{\circ}\right)$. These patients have mild anemia, and $<20 \%$ have palpable spleen $[25,26]$.

3. $\beta$-thalassemia intermedia; this term is useful clinically, but does not correlate with its genetic or clinical mechanism for the phenotype [27,28]; usually used to describe $\beta$-thalassemia patients who do not require chronic red cell transfusion in early childhood, although by the second decade of life they may present the same picture as $\beta$-thalassemia major [28]. Most of the patients have homozygous partial production defect of $\beta$ globin $\beta^{+} \beta^{+}$or $\beta^{+} \beta^{\circ}$, and there are many co-inheritance factors that influence the clinical spectrum (Table 1). Patients with $\beta$-thalassemia intermedia frequently develop moderate to severe skeletal changes because of bone marrow expansion, osteoporosis, leg ulcers, gallstones, and pulmonary hypertension and have an increased predisposition to thrombosis as compared to thalassemia major [29-33]. Cardiac involvement in thalassemia intermedia results mainly from a high-output state and pulmonary hypertension, while systolic left ventricle function is usually preserved [31]. These patients have a spectrum of severity, but all have complications in common:

a. Chronic anemia: high cardiac output, increased pulmonary vascular resistance, pulmonary hypertension, and heart failure

b. Iron overload: because the patients are not receiving chronic transfusion, there is increased gut iron absorption with subsequent symptoms and signs of iron overload

Treatment of individuals with thalassemia intermedia is symptomatic [33]. As hypersplenism may cause worsening anemia, retarded growth, and mechanical disturbance from the large spleen, splenectomy is recommended. Prevention of post- 
Table 2 The phenotype and genotypes of $\beta$-thalassemia

\begin{tabular}{lllll}
\hline Phenotypes & Genotype & MCV & Anemia & Hb electrophoresis \\
\hline Silent carrier & $\beta \beta^{+}$ & Low/Normal & None & Normal \\
Minor (Trait) & $\beta \beta^{\circ}$ & Low & Mild & High Hb A \\
Intermedia & $\beta^{+} \beta^{+}$and others & Low & Moderate & Presence of small amount of A and could be similar to Major \\
Major & $\beta^{\circ} \beta^{\circ}$ & Low & Severe & Hb A absent, only Hb A and Hb F are present \\
\hline
\end{tabular}

$H B$ hemoglobin, $H b A$ adult hemoglobin, $H b F$ fetal hemoglobin, $M C V$ mean corpuscular volume.

splenectomy sepsis includes standard immunization and antibiotic prophylaxis. The gallbladder should be inspected during splenectomy and removed in all cases to prevent gallstones. Treatment of extramedullary erythropoietic masses, detected by magnetic resonance imaging, is based on radiotherapy, transfusions, or hydroxycarbamide. Leg ulcer requires regular blood transfusions, zinc supplementation, hydroxycarbamide, pentoxifylline, and possibly erythropoietin and platelet-derived growth factor. The high risk of thrombosis, exacerbated by splenectomy, requires proper anticoagulation and/or antiplatelet agents prior to surgical or other high-risk procedures. Chelation therapy is essential to prevent iron overload. In some Arabian Gulf countries, patients with known thalassemia intermedia mutations (e.g., Hb Dhofar) are regularly hyper-transfused from the beginning to avoid the serious complications of excessive medullary and extra-medullary haematopoiesis $[34,35]$.

4. $\beta$-thalassemia major (transfusion-dependent $\beta$ thalassemia); total impairment of $\beta$-globin chain production leading to excess $\alpha$-globin chain, which in turn is unable to form soluble tetramers and is precipitated in the cell, leading to a sequence of cellular and clinical events. These patients are well at birth, and the clinical picture will start after the fetal $\mathrm{Hb}(\mathrm{Hb} \mathrm{F})$ switch to adult $\mathrm{Hb}(\mathrm{Hb} \mathrm{A})$ fails because there is no $\beta$-chain produced, leading to anemia, which usually starts after 6 months of age. The severity of phenotype is heterogeneous depending on the type of mutation influencing the $\beta$-chain production, e.g., $\beta^{\circ}, \beta^{+}$, the balance between $\alpha$ - and $\beta$-chain and $\mathrm{Hb} \mathrm{F}$ production [27,29,30,36-39]. The manifestations in untreated patients include pallor, irritability, cardiac failure, growth failure, hepato-splenomegaly, bone abnormality, and features of hemolysis. The majority of untreated patients under the age of 5 years die due to anemia, heart failure, or infections [27,40-45].

The patients who have severe $\beta$-thalassemia develop symptoms in the first year of life with progressive anemia, failure to thrive, poor feeding, intermittent bouts of infection, and general malaise in most cases. These infants are pale and, in many cases, splenomegaly is already present. A few patients might present as late as between the third to fifth year of age $[27,30,46]$. The diagnosis of $\beta$-thalassemia requires a patient history, physical examination, and confirmatory laboratory tests including complete blood count and blood film morphology, both demonstrating microcytic hypochromic anemia, and confirmation by alkaline $\mathrm{Hb}$ electrophoresis (Table 2) [46].

The features of the different presentations of thalassemia syndromes are:

1. $\beta$-thalassemia silent carrier

- Normal phenotype

- Laboratory: normal Hb, RBC indices, and $\mathrm{Hb}$ electrophoresis

2. $\beta$-thalassemia minor (trait)

- Haematocrit $>30 \%$

- $\mathrm{Hb}$ and peripheral morphology similar to iron deficiency state

- RBC count more than normal, MCV is low

- RDW is normal

- Hb electrophoresis or HPLC show elevated Hb $\mathrm{A}_{2}$ (except in rare cases will be normal)

3. $\beta$-thalassemia intermedia

- Hb is low (6-10 g/dL)

- $\mathrm{CBC}$ and peripheral morphology are variable with hypochromic, microcytic changes with variation in $\mathrm{RBC}$ size and shape

- RDW is increased

- Hb electrophoresis or HPLC show different patterns; some patients are able to produce $\mathrm{Hb} \mathrm{A}$ in small quantities or similar to homozygous $\beta$ thalassemia zero where $\mathrm{Hb} \mathrm{A}$ is absent

4. $\beta$-thalassemia major

- CBC:

- False elevated WBC because of nucleated RBC

- Severe anemia with $\mathrm{Hb}$ as low as 3-4 g/dL

- Microcytic hypochromic picture with fragmented RBC, tear drops, target cells, and $\mathrm{RBC}$ with inclusion bodies

- Reticulocyte count low

- Serum iron to TIBC is high 
- Hb electrophoresis: absent $\mathrm{Hb} \mathrm{A}$ with remaining as $\mathrm{Hb} \mathrm{F}$ and $\mathrm{Hb} \mathrm{A}_{2}$ (Table 2)

The final step in a diagnostic approach is to perform DNA studies on the genetic material extracted from peripheral blood. This will identify the type of the mutation and help identify the silent carriers [18].

\section{Transfusion therapy in thalassemia}

Red cell transfusions are required to increase the oxygen-carrying capacity of the blood through raising the $\mathrm{Hb}$ concentration of patients with acute or chronic anemia [1]. Guidelines for the transfusion of blood and blood components and the management of transfused patients are in accordance with the British Committee for Standards in Haematology [47]. The major goals for blood transfusion therapy include $[48,49]$ :

1. Maintenance of red cell viability and function during storage to ensure sufficient transport of oxygen

2. Use of donor erythrocytes with a normal recovery and half-life in the recipient

3. Achievement of appropriate $\mathrm{Hb}$ level

4. Avoidance of adverse reactions, including transmission of infectious agents.

\section{Current practice and recommendation for transfusion therapy in Arabian Gulf countries}

The recommended treatment for thalassemia major involves lifelong, regular blood transfusions, usually administered every 2 to 5 weeks to maintain the pretransfusion $\mathrm{Hb}$ level above 9.5-10.5 g/dL [50,51]. However, in most of the Gulf countries, $9 \mathrm{~g} / \mathrm{dL}$ is accepted as the minimum pre-transfusion $\mathrm{Hb}$ level. Higher levels (11-12 g/dL) may be needed for patients with cardiac complications. The post-transfusion $\mathrm{Hb}$ is kept not higher than $14-15 \mathrm{~g} / \mathrm{dL}$.

Our practice includes extended red cell antigen typing of patients including C, E, and Kell before the first transfusion. At each transfusion, we do a full cross match and screening for the new antibodies. Matching for C, E, and Kell antigens is only done for negative patients. The blood is leuko-reduced with pre-storage filtrations. Some countries also practice bed-side filtrations. Transfusion is attended by nurses who report any adverse reactions. Blood that has not been transfused by 4 hours after hooking is discarded.

\section{Iron overload}

During the introduction of a regular transfusion program in the early 1960s, an iron chelating agent demonstrated improved survival. However, iron overload is still one of the most critical issues, and its complications remain the most important cause of morbidity and mortality [52,53]. In addition, the lack of adherence to an iron chelating agent regimen is considered an important factor in suboptimal clinical improvement and poor prognosis [54]. Many significant developments have been made in the assessment of iron overload, and advances in the modalities available for iron chelation have expanded treatment options and improved treatment management.

In a chronically transfused patient, one unit of blood contains $200 \mathrm{mg}$ iron [55]. Since humans have no physiologic mechanism for active elimination of excess iron, patients receiving regular $\mathrm{RBC}$ transfusions develop cumulative iron overload and are at risk for iron toxicity [55].

In addition to the transfused iron, thalassemia patients absorb more iron than normal individuals. The mechanism of increased absorption in thalassemia patients is thought to be related to paradoxical Hepcidin suppression from dys-erythropoiesis [56]. Free iron is subsequently deposited primarily in parenchymal cells of different organs. Then it will participate in oxidative reactions to generate free oxygen radicals, which can lead to chronic cell toxicity and DNA damage [57].

\section{Measurements of iron load}

Parameters used to monitor iron load include serum ferritin, liver biopsy, and MRI assessment of liver and cardiac iron, in conjunction with functional testing such as echocardiography, liver function test, and measures of endocrine function.

\section{Serum ferritin}

Serum ferritin is the most commonly used parameter for monitoring iron overload despite its inaccuracy and limitation in assessing the body iron overload. It is a valuable method to roughly assess the long-term, overall status of iron overload and to monitor response to chelation therapy. It is also valuable due to its ease of measurement and wide availability, and it correlates with cardiac impairment and survival but not with hepatic iron [58]. Serum ferritin is elevated in many other conditions such as infections, inflammation, or malignancy. Iron overload is generally defined as serum ferritin consistently $\geq 1000 \mathrm{ng} / \mathrm{L}$ [59]. It is recommended to know the baseline level of ferritin and to assess the trend by taking serial measurement of serum ferritin every 3 months. In the Gulf area, due to the wide availability of the test in all treating centers, the test is done on a monthly basis.

\section{Liver biopsy}

Liver iron concentration remains the most accurate measure of total body iron loading [60], and liver biopsy was previously considered to be the gold standard of 
liver iron assessment, but is an invasive procedure associated with a risk of complications. Liver biopsy is still performed to evaluate liver fibrosis, cirrhosis, or hepatocellular carcinoma, which are possible complications in all patients with liver iron overload. It is well known that a hepatic iron level of 7-15 mg/g dry weight is associated with an increased risk of complications; a higher level increases risk of cardiac disease and early death. However, because of its invasive nature and lack of cultural acceptance, this test is rarely performed in the Gulf area centers.

\section{MRI assessment of liver iron}

MRI is the method of choice in the monitoring of various organs' iron levels where the measurement of tissue proton transverse relaxation rates (R2) was shown to have excellent correlation with liver iron concentration measured by biopsy [61]. An annual monitoring of R2 MRI is recommended, which can be extended to every 2 years for patients with normal liver iron or at the lower end of the ideal iron range of less than $7 \mathrm{mg} / \mathrm{g}$ dry weight. Additionally, liver iron levels should also be correlated with standard liver function tests.

\section{MRI assessment of cardiac iron}

Similar to liver iron measurement, MRI has been widely used to annually monitor iron levels in the heart where the measurements of $\mathrm{T} 2 \%$, a relaxation parameter intrinsic to protons placed in the magnetic field, is utilized [62]. In the Gulf region, very few centers have this tool available. It is recommended to expand this service for thalassemia patients because MRI is a noninvasive, reliable, and accurate method of assessing iron overload.

\section{Chelating agents}

There are 3 main available chelators: deferoxamine, deferiprone, and deferasirox (Table 3); deferiprone and deferasirox are oral chelators that have come into the clinic in recent years. They are different in molecular weight, leading to differences in intestinal absorption. For several decades, the only available iron chelator was deferoxamine [58].

In the Gulf region, deferoxamine has been available since the early 1970s, and nowadays it is much less widely used except in combined chelation therapy. In 1999, deferiprone was introduced to Oman and has been widely used as monotherapy or combined therapy. In other Gulf States it was introduced in early 2000s. Although the international guidelines recommend the use of deferiprone after the age of 6 years, in some Arabian Gulf countries the syrup formulation has been widely used with good efficacy for children 2 years and above with no serious complications. In a recent study, continued deferiprone therapy during episodes of mild

Table 3 Comparative analysis of different iron chelators

\begin{tabular}{|c|c|c|c|}
\hline & Deferoxamine (DFO) & Deferiprone (DFP) & Deferasirox (DFX) \\
\hline Brand name & Desferal & Ferriprox & Exjade \\
\hline $\begin{array}{l}\text { Chelator-iron, } \\
\text { complex ratio }\end{array}$ & Hexadentate, 1:1 & Bidentate, 3:1 & Tridentate, 2:1 \\
\hline $\begin{array}{l}\text { Dose }(\mathrm{mg} / \mathrm{kg} / \\
\text { day) }\end{array}$ & $25-50$ & $75-100$ & $20-40$ \\
\hline $\begin{array}{l}\text { Combination } \\
\text { and titration } \\
\text { doses }(\mathrm{mg} / \mathrm{kg} / \\
\text { day) }\end{array}$ & \multicolumn{2}{|c|}{ Combination therapy with DFO and DFP, 2 days/week DFO and then continue with DFP } & Titration therapy \\
\hline Administration & $\begin{array}{l}\text { Subcutaneous or intravenous, 8-10 hrs/day, } \\
5-7 \text { days/wk }\end{array}$ & Oral, 3 times daily & Oral, once daily \\
\hline $\begin{array}{l}\text { Plasma } \\
\text { half-life (hr) }\end{array}$ & 0.5 & $2-3$ & $8-16$ \\
\hline $\begin{array}{l}\text { Route of } \\
\text { elimination }\end{array}$ & Biliary and urinary & Urinary & Biliary \\
\hline $\begin{array}{l}\text { Regulatory } \\
\text { approval }\end{array}$ & US, Canada, Europe, other countries & US, Europe, other countries & US, Canada, Europe, other countries \\
\hline Indication & $\begin{array}{l}\text { Transfusion iron overload and acute iron } \\
\text { overload }\end{array}$ & $\begin{array}{l}\text { Transfusion iron overload when DFO is } \\
\text { contraindicated or inadequate }\end{array}$ & Transfusion iron overload \\
\hline $\begin{array}{l}\text { Adverse } \\
\text { events }\end{array}$ & $\begin{array}{l}\text { Irritation at the infusion site, ocular and } \\
\text { auditory disturbances, growth retardation and } \\
\text { skeletal changes, allergy, respiratory distress } \\
\text { syndrome with higher doses }\end{array}$ & $\begin{array}{l}\text { Agranulocytosis and neutropenia, } \\
\text { gastrointestinal disturbances, arthropathy, } \\
\text { increased liver enzyme levels, low plasma } \\
\text { zinc level, hepatic fibrosis }\end{array}$ & $\begin{array}{l}\text { Gastrointestinal disturbances, rash, } \\
\text { increase in serum creatinine level; } \\
\text { potentially fatal renal impairment } \\
\text { or failure }\end{array}$ \\
\hline $\begin{array}{l}\text { Advantage/ } \\
\text { Disadvantage }\end{array}$ & Inexpensive/ Compliance & Route of administration / Compliance & Route of administration / Expensive \\
\hline
\end{tabular}


neutropenia (down to $1 \times 10^{9} / \mathrm{L}$ ) has not been associated with progression to agranulocytosis [63]. We recommend giving extensive counseling to the patients, with clear instructions to report to hospital emergency in case of fever and to have an urgent CBC with ANC count.

Deferasirox has been available in the Gulf area since 2007. It has been widely used across all the Gulf countries. Side effects are comparable (Table 3) to those published in the literature [64], and its efficacy has been demonstrated in many clinical trials [65]. It is used only as monotherapy. Some patients do not respond to the maximum dose of $40 \mathrm{mg} / \mathrm{kg} /$ day, however, and compliance may be an issue with this drug, just as it is for the other available chelators.

\section{Hematopoietic stem cell transplantation (HSCT) for thalassemia}

HSCT has the potential to be curative for thalassemia major and has been increasingly adopted, with cautions. The first two cases of HSCT for thalassemia were performed in 1981, one in Seattle, Washington, and the other in Pesaro, Italy [66]. Since 1981, a large clinical experience has been gained with more than 2,000 HCSTs in centers around the world. The patient classes have been identified on the basis of 3 risk factors (the Pesaro classification): inadequate iron chelation therapy, presence of liver fibrosis, and hepatomegaly (Table 4) [67].

\section{Factors to be taken into consideration for HSCT in thalassemia}

\section{Age}

Since gonadal damage occurs with the myeloablative conditioning regimens currently used in thalassemia transplants, it is important to try to perform transplant as early as possible to minimize infertility. An age range of 2-5 years may seem reasonable [68]. For several reasons an earlier patient age at transplant has a better outcome because a fewer number of transfusions (allosensitization) would decrease the chances of rejection, and complications of iron overload and organ and

Table 4 Stem cell transplantation for thalassemia

\begin{tabular}{llll}
\hline & Class I & Class II & Class III \\
\hline Number of risk factors & None & $1-2$ & 3 \\
Survival (\%) & 93 & 87 & 79 \\
Event free survival (\%) & 91 & 83 & 58 \\
Rejection (\%) & 2 & 3 & 28 \\
$\begin{array}{l}\text { Risk of transplant-related } \\
\text { mortality (\%) }\end{array}$ & 8 & 15 & 19 \\
$\begin{array}{l}\text { Risk of transplant-related } \\
\text { morbidity (\%) }\end{array}$ & 9, mainly & 17 & 22 \\
\hline
\end{tabular}

GVHD graft-versus-host disease. transplant-related toxicity will be less. Accordingly, tolerance for myeloablative conditioning regimens would be better compared with older age groups and adults $[68,69]$.

\section{Conditioning}

The standard conditioning regimen that is practiced in most HSCT units all over the world, especially for class I and II patients, consists of busulfan and cyclophosphamide and GVHD prophylaxis in the form of cyclosporine A and methotrexate [70,71]. New developments in conditioning regimens have taken place over the last decade. The introduction of IV busulfan with drug level monitoring and IV fludarabine improved the efficacy and reduced the toxicity of transplant outcome [72]. In addition, HSCT outcome for patients of older age with advanced disease receiving a second transplant improved markedly with improved pre-transplantation preparation and simultaneous use of myeloablative and prolonged immune suppression. In order to be utilized effectively and to minimize toxicity and rejection, it is important that busulfan levels are monitored and doses adjusted accordingly [72,73]. Several centers have recently reported using new therapeutic conditioning regimens utilizing the combination of treosulfan, thiotepa, and fludarabine because treosulfan does not require therapeutic drug monitoring. The outcome of the new regimen may be effective and safer even for more advanced thalassemia and may replace busulfan as the conditioning of choice [74,75].

\section{Matched umbilical cord as stem cell source}

While HSCT from a bone marrow harvest of a fully HLA-matched donor is the recommended option, genetically matched umbilical cord blood can be a suitable source [76]. This provides an alternate source of stem cells with minimal risk to the donor. In the Gulf area, experience with this form of HSCT is still very limited.

\section{Results of HSCT for thalassemia in the Gulf area}

Two countries are doing HSCT, namely Oman and Saudi Arabia. Between 1996 and 2010, a total of 47 patients with thalassemia major underwent matched sibling donor HSCTs in Oman. Most received busulfan and cyclophosphamide with or without ATG, while more recently patients received busulfan and fludarabine. Eighty-nine percent are alive and free from thalassemia at a median follow-up of 125 months (22-197 months). Graft rejection was $8.5 \%$, and transplant-related mortality was $4.3 \%$ [77].

In Saudi Arabia, transplants in 60 thalassemic patients were done between January 1998 and July 2006 from HLA-related, matched donors. The overall survival and event-free survival were $94 \%$ and $77 \%$, respectively [69]. 


\section{Complications in thalassemia}

Iron overload can be either from thalassemia itself or from frequent blood transfusions. The damage is characterized by excessive iron deposition without adequate iron chelation therapy; almost all patients with $\beta$-thalassemia will accumulate potentially fatal iron levels [78]. A range of complications including endocrinopathies, hypersplenism, infertility, hepatobiliary, musculoskeletal, and cardiopulmonary can arise. Complications are linked to overstimulation of the bone marrow, dysfunctional erythropoiesis, an increase in iron burden, imbalance of oxidant/antioxidant ratio, and chelation of essential elements such as zinc.

\section{Endocrinopathies}

Endocrinopathies are characterized by poor growth; delayed puberty, infertility, and impaired glucose tolerance are some complications that can occur in thalassemia patients [79-81]. Hypogonadism is a common complication that occurs due to a high iron burden [82-85]. Endocrine complications arise possibly due to factors that influence the anterior pituitary gland, which might be due to free radical oxidative stress damage for the pituitary and hypothalamus leading to growth hormone deficiency, resulting in delayed growth and infertility $[85,86]$.

Early and appropriate management is crucial in $\beta$ thalassemia patients, and hormone therapy is an effective option in the management of hypogonadism [87]. Hormone therapy to young $\beta$-thalassemia patients with low iron burden can induce increases in height, growth, and stimulate puberty $[83,88]$. Initiating aggressive and appropriate chelation therapy is important along with hormone therapy to minimize iron deposition in the endocrine glands. Along with hormone therapy, zinc supplementation is recommended in patients who have growth impairment and low serum zinc levels [85,89].

\section{Hypersplenism}

Hypersplenism is another complication in patients who have either thalassemia major or thalassemia intermedia, leading to compromised immune function. It is associated with leukopenia, thrombocytopenia, and increased requirement for transfusions. Splenomegaly (enlarged spleen) develops in these patients, often requiring a splenectomy, which is conducted to reduce the need for red cell transfusion [89-92].

\section{Infertility/pregnancy}

In women with $\beta$-thalassemia, infertility is a common issue due to iron deposition and oxidative damage to endocrine organs as a result of blood transfusions. However, with advances in the management of thalassemia, chances of conceiving have increased and pregnancy has become more prevalent, but pregnancy is not recommended in women who have cardiac dysfunction [93]. For women who are at high risk of iron overload and who intend to conceive, an echocardiography is recommended before conception and during pregnancy to evaluate cardiac function [94].

Management of pregnant women with thalassemia major requires blood transfusions and maintaining a $\mathrm{Hb}$ level of at least $10 \mathrm{~g} / \mathrm{dL}$ [93]. According to the American Congress of Obstetricians and Gynecologists (ACOG) guidelines, iron chelation therapy with deferoxamine is not recommended during pregnancy because its safety has not been well established $[93,95]$. For patients who are at high risk of increased iron deposition in the heart and liver, oral chelation therapy should be used with caution [95]. Administration of deferasirox to animals during pregnancy and lactation resulted in reduced offspring viability [96]. It is important to note that the oral chelator deferiprone is a fairly small molecule that can cross the placenta, and therefore it is contraindicated in pregnancy [97]. After pregnancy, patients can resume iron chelation therapy.

\section{Hepatobiliary disorders}

It has been documented that within 2 years of transfusion initiation, hepatocellular injury can occur when the liver iron concentrations exceed normal levels, leading to tissue damage, collagen formation, and portal fibrosis [98]. Furthermore, in the presence of infections such as hepatitis $\mathrm{C}$ virus infection, there is increased risk of the development of liver fibrogenesis. Reducing iron burden would reduce liver fibrosis and improve survival in $\beta$ thalassemia patients since liver iron concentrations greater than $7 \mathrm{mg} / \mathrm{g}$ dried weight are shown to be linked to increased morbidity and mortality [98]. Furthermore, $\beta$-thalassemia patients might potentially benefit from combination therapy with iron chelators and green tea extract to decrease the progression of liver fibrosis [99].

\section{Musculoskeletal}

Patients with thalassemia may exhibit dramatic skeletal abnormalities, frequently leading to marked structural changes and delayed skeletal maturation, due to the expansion of erythroid bone marrow, which widens the marrow spaces, attenuates the cortex and produces osteoporosis. The skull and facial bones are often strikingly abnormal, there is prominent frontal bossing, delayed pneumatization of the sinuses, and marked overgrowth of the maxillae. Premature fusion of the epiphyses can result in characteristic shortening of the limbs, particularly the arms. Of equal concern is the thinning of the cortices due to marrow expansion, which often results in pathologic fractures [100]. 
Bone disease in thalassemia is also attributable to additional factors including iron deposit in bone, vitamin D deficiency, and deferoxamine toxicity in bone. The interactions among iron, hemopoietic cells, osteoblasts, and osteoclasts in bone tissue have never been explained $[101,102]$. There is now a growing awareness that many transfusion-dependent adult patients with $\beta$-thalassemia major and intermedia suffer from long-standing bone pain, low bone mass, and fractures.

Current transfusion and chelation practices might be insufficient to prevent the development of low bone mass, and additional strategies to improve bone mineral density are required. There is a need for clinical trials to determine the appropriate form of hormone replacement therapy along with vitamin D supplementation as other strategies to optimize bone accrual in this disease. In thalassemia patients with iron overload, regular assessment of bone density from puberty every 2 years if normal, and annually if abnormal, might be required. Additionally, it is necessary to ensure adequate calcium intake, sun exposure, and vitamin D intake. Bisphosphonate therapy may be indicated if osteoporosis is documented [103].

\section{Cardiopulmonary}

Cardiopulmonary dysfunction represents one of the most under-diagnosed complications. The main cardiac abnormalities reported in patients with thalassemia major and iron overload are left ventricular systolic and diastolic dysfunction, pulmonary hypertension, arrhythmias, and pericarditis. These cardiac abnormalities are closely related to concomitant endocrine deficiencies, thromboembolic events, and inflammatory milieu $[104,105]$.

Iron-induced cardiomyopathy is slowly progressive, and it usually takes several decades for clinical or laboratory features of cardiac dysfunction to manifest [106-108]. Cardiac complications represent the leading cause of mortality in thalassemia major with uncontrolled iron overload. Following the introduction of chelating therapies, an important and progressive increase of life expectancy mainly due to improvement of cardiac dysfunction has been demonstrated [106-108].

Pulmonary impairment is shown in a great proportion of patients, even among asymptomatic young patients, thus, regular screening of pulmonary function should be adopted in the routine clinical follow-up of these patients [109]. Pulmonary hypertension is common in thalassemia and contributes to mortality. Advancing age and a history of splenectomy are major risk factors in this population. Guidelines for the management of pulmonary hypertension in thalassemia have not yet been established, however, clinical trials are ongoing in an effort to guide future therapy $[90,110,111]$.

\section{Psychosocial impact}

Psychosocial and behavioral problems are common in thalassemia patients and their family, suggesting the importance of lifelong psychosocial support [112]. Based on the conclusions of previous studies, it was recommended that medical therapy of these patients should be supported with psychological and psychiatric therapy. Chronicity is a powerful source of emotional problems that intensify at each significant developmental stage of the patient's life. Patients can feel that they are different, limited, or isolated. Their state of mind can shift rapidly from depression to anger and vice versa. Health workers must be prepared to accept this shift and to help patients deal with these feelings and to find their own way of normal life $[113,114]$. Several objectives have to be achieved to reach the goal of optimal psychosocial integrity of the patients, including:

1. Educate patients and parents to understand the magnitude of the illness.

2. Provide support to patients to be able to take care of themselves.

3. Facilitate a normal lifestyle and encourage patients in ways to develop a normal adult life.

These objectives can be achieved by the support of a well-trained, multidisciplinary team who understands chronic hereditary diseases.

\section{Future treatment options and prevention Stem cell transplantation}

Improvement in the life expectancy of patients with $\beta$ thalassemia major is due to effective transfusion and iron chelation therapy. However, the only current curative treatment is stem cell transplantation, which is becoming more utilized in good patient candidates, and several centers are doing it in the Gulf States-in particular Saudi Arabia. Production of fetal $\mathrm{Hb}$ by cytotoxic agents such as demethylation agents and hydroxyurea, has been explored over the last two decades $[115,116]$.

\section{Prevention}

Prevention of thalassemia is the only solution to efficiently reduce the huge medical, social, and economic impact in countries where it occurs with high frequency. Premarital screening became mandatory for hemoglobinopathies in Saudi Arabia with the intention to decrease the prevalence of the disease [115,117]. Preimplantation genetic diagnosis is an important option for couples at risk of having children with $\beta$-globin mutations [118]. Some premarital and antenatal screening centers in the Gulf area refrain from aborting fetuses owing to religious and cultural reasons. Public awareness 
and related social activities are important tools to improve the understanding of the burden of this disease and of how to support preventive programs aiming to eradicate this disease.

\section{Conclusions}

The prevalence of thalassemia syndrome in the Arabian Gulf area necessitates more work to estimate the size of this health problem and its impact on the community and the quality of life of the patients and their families. The rationale behind the interest in thalassemia is its responsiveness to treatment with regular blood transfusion and the reversibility of complications with iron chelation. In the Gulf States there is a great potential for improving the quality of care provided to thalassemia patients, hence this manuscript was prepared to emphasize the importance of neonatal screening programs.

Efforts of the health care providers should be directed to improve the early diagnosis and management of $\beta$-thalassemia through enrolling the patients in a Thalassemia Center of Excellence to ensure the maximum service and to prevent disease complications. Pre-implantation genetic diagnosis is an option that has become widely accepted religiously and socially to prevent severe $\beta$-thalassemia in the Gulf Countries.

\section{Competing interests}

The authors declare that they have no competing interests.

\section{Authors' contributions}

The authors had 3 meetings over a 9 month period to summarize the evidences based on published data and to bring their expertise in the management of thalassemia patients. All authors contributed to the writing and integration of the different segments of the manuscript. All authors read and approved the final manuscript.

\section{Acknowledgements}

This work was funded in part through an unrestricted grant from ApoPharma Inc., Toronto, Canada. Kelly A. Keating (Albany College of Pharmacy and Health Sciences) edited the manuscript for English language and organization.

\footnotetext{
Author details

${ }^{1}$ College of Medicine, King Abdul Aziz University, Jeddah, Saudi Arabia. ${ }^{2}$ College of Medicine, SQU, Muscat, Oman. ${ }^{3}$ Maternity and Children Hospital, Al Ahsa, Saudi Arabia. ${ }^{4}$ Prince Sultan Military Medical City, Riyadh, Saudi Arabia. ${ }^{5}$ Clinical Hematology Unit, Department of Medical Oncology, National Centre for Cancer Care and Research, Hamad Medical Corporation, Doha, Qatar. ${ }^{6}$ College of Medicine \& KKUH, King Saud University, Riyadh, Saudi Arabia. ${ }^{7}$ King Faisal Specialist Hospital and Research Center, Riyadh, Saudi Arabia. ${ }^{8}$ Department of Medicine, Qatif Central Hospital, Qatif Eastern Province, Saudi Arabia. ${ }^{9}$ Princess Noura Oncology Center, King Abdulaziz Medical City, Jeddah, Saudi Arabia. ${ }^{10}$ Dubai Health Care City, Dubai, United Arab Emirates. ${ }^{11}$ Hopitaux Du Leman, Annemasse, France. ${ }^{12}$ The Pharmaceutical Research Institute at Albany College of Pharmacy and Health Sciences, Rensselaer, New York, USA.
}

Received: 14 June 2013 Accepted: 6 September 2013 Published: 17 September 2013

\section{References}

1. Higgs DR, Engel JD, Stamatoyannopoulos G: Thalassaemia. Lancet 2012, 379:373-383.

2. Viprakasit V, Lee-Lee C, Chong QT, Lin KH, Khuhapinant A: Iron chelation therapy in the management of thalassemia: the Asian perspectives. Int J Hematol 2009, 90:435-445.

3. Akhtar MS, Qaw F, Borgio JF, Albuali W, Suliman A, Nasserullah Z, Al-Jarrash S, Al-Ali A: Spectrum of alpha-thalassemia mutations in transfusiondependent beta-thalassemia patients from the Eastern Province of Saudi Arabia. Hemoglobin 2013, 37:65-73

4. Thalassemia. http://www.cdc.gov/ncbddd/blooddisorders/documents/ BBV_PNV_CO_1159_Thalassemia_R2mtr.pdf.

5. Nienhuis AW, Nathan DG: Pathophysiology and Clinical Manifestations of the beta-Thalassemias. Cold Spring Harb Perspect Med 2012, 2:a011726.

6. Cappellini MD, Cohen A, Piga A, Bejaoui M, Perrotta S, Agaoglu L, Aydinok Y, Kattamis A, Kilinc Y, Porter J, Capra M, Galanello R, Fattoum S, Drelichman G, Magnano C, Verissimo M, Athanassiou-Metaxa M, Giardina P, KourakliSymeonidis A, Janka-Schaub G, Coates T, Vermylen C, Olivieri N, Thuret I, Opitz H, Ressayre-Djaffer C, Marks P, Alberti D: A phase 3 study of deferasirox (ICL670), a once-daily oral iron chelator, in patients with beta-thalassemia. Blood 2006, 107:3455-3462.

7. Wood JC, Claster S, Carson S, Menteer JD, Hofstra T, Khanna R, Coates T: Vitamin D deficiency, cardiac iron and cardiac function in thalassaemia major. Br J Haematol 2008, 141:891-894.

8. Muncie $\mathrm{HL} \mathrm{Jr}$, Campbell J: Alpha and beta thalassemia. Am Fam Physician 2009, 80:339-344.

9. Quek L, Thein SL: Molecular therapies in beta-thalassaemia. $\mathrm{Br} J$ Haematol 2007, 136:353-365.

10. Verma IC, Kleanthous M, Saxena R, Fucharoen S, Winichagoon P, Raizuddin S, Khan SN, Akbari MT, Izadyar M, Kotea N, Old JM, loannou PA, Khan B: Multicenter study of the molecular basis of thalassemia intermedia in different ethnic populations. Hemoglobin 2007, 31:439-452.

11. Alamiry AAN, Ali TH, Majeed MN: Detection of Hemoglobinopathies in Hypochromic, Microcytic and Sickeled Cell Blood Films by Hemoglobin Electrophoresis. Thi-Qar Med J 2011, 5:139-148.

12. Al-Sulaiman A: Prevalence of $\beta$-thalassemia trait in premarital screening in Al-Hassa, Saudi Arabia. Ann Saudi Med 2006, 26:14-16.

13. Nadkarni KV, Al-Arrayed SS, Bapat JP: Incidence of Genetic Disorders of Hemoglobins in the Hospital Population of Bahrain. Bahrain Med Bull 1991, 13.

14. Fawzi ZO, Al Hilali A, Fakhroo N, Al Bin Ali A, Al Mansour S: Distribution of Hemoglobinopathies and Thalassemias in Qatari Nationals Seen at Hamad Hospital in Qatar. Qatar Med J 2003, 12.

15. White JM, Byrne M, Richards R, Buchanan T, Katsoulis E, Weerasingh K: Red cell genetic abnormalities in Peninsular Arabs: sickle haemoglobin, G6PD deficiency, and alpha and beta thalassaemia. J Med Genet 1986, 23:245-251.

16. Rajab AG, Patton MA, Modell B: Study of hemoglobinopathies in Oman through a national register. Saudi Med J 2000, 21:1168-1172.

17. Al-Riyami A, Ebrahim GJ: Genetic Blood Disorders Survey in the Sultanate of Oman. J Trop Pediatr 2003, 49(Suppl 1):i1-20.

18. Al-Sultan A, Phanasgaonkar S, Suliman A, Al-Baqushi M, Nasrullah Z, Al-Ali A: Spectrum of beta-thalassemia mutations in the eastern province of Saudi Arabia. Hemoglobin 2011, 35:125-134.

19. Pembrey ME, Perrine RP, Wood WG, Weatherall DJ: Sickle beta 0 thalassemia in Eastern Saudi Arabia. Am J Hum Genet 1980, 32:26-41.

20. Flint J, Harding RM, Boyce AJ, Clegg JB: The population genetics of the haemoglobinopathies. Baillieres Clin Haematol 1998, 11:1-51.

21. Zahed $L$ : The Spectrum of beta-Thalassemia Mutations in the Arab Populations. J Biomed Biotechnol 2001, 1:129-132.

22. El-Hazmi MA, Warsy AS, Al-Swailem AR: The frequency of 14 betathalassemia mutations in the Arab populations. Hemoglobin 1995, 19:353-360.

23. Baysal E: Molecular heterogeneity of beta-thalassemia in the United Arab Emirates. Community Genet 2005, 8:35-39.

24. Aydinok Y: Thalassemia. Hematology 2012, 17(Suppl 1):S28-31.

25. Tassiopoulos T, Rombos Y, Konstantopoulos K, Revenas K, Tassiopoulos S, Aessopos A: Spleen size in beta-thalassaemia heterozygotes. Haematologia (Budap) 1995, 26:205-209. 
26. Karimi M, Bagheri MH, Tahmtan M, Shakibafard A, Rashid M: Prevalence of hepatosplenomegaly in beta thalassemia minor subjects in Iran. Eur J Radiol 2009, 69:120-122.

27. Olivieri NF: The beta-thalassemias. N Engl J Med 1999, 341:99-109.

28. Aessopos A, Farmakis D, Karagiorga M, Voskaridou E, Loutradi A, Hatziliami A, Joussef J, Rombos J, Loukopoulos D: Cardiac involvement in thalassemia intermedia: a multicenter study. Blood 2001, 97:3411-3416.

29. Taher AT, Musallam KM, El-Beshlawy A, Karimi M, Daar S, Belhoul K, Saned MS, Graziadei G, Cappellini MD: Age-related complications in treatmentnaive patients with thalassaemia intermedia. $\mathrm{Br} J$ Haematol 2010 , 150:486-489.

30. Forget B: Thalassemia Syndromes. In Hematology: Basic Principles and Practice. 3rd edition. Edited by Hoffman R, Benz EJ, Shattil S, Furie B, Cohen H, Silberstein L, McGlave P. New York: Churchill Livingstone; 2000.

31. Galanello R, Origa R: Beta-thalassemia. Orphanet J Rare Dis 2010, 5:11.

32. Cao A, Galanello R: Beta-thalassemia. Genet Med 2010, 12:61-76.

33. Cappellini MD, Musallam KM, Taher AT: Insight onto the pathophysiology and clinical complications of thalassemia intermedia. Hemoglobin 2009, 33(Suppl 1):S145-159.

34. Daar S, Gravell D, Hussein HM, Pathare AV, Wali Y, Krishnamoorthy R: Haematological and clinical features of beta-thalassaemia associated with Hb Dhofar. Eur J Haematol 2008, 80:67-70.

35. Tony S, Daar S, Elshinawy M, Al-Zadjaly S, Al-Khabori M, Wali Y: T2* MRI in regularly transfused children with thalassemia intermedia: serum ferritin does not reflect liver iron stores. Pediatr Hematol Oncol 2012, 29:579-584.

36. Bunn H, Forget B: Hemoglobin: Molecular, Genetic and Clinical Aspects. Philadelphia: W B Saunders Co.; 1986

37. Weatherall D: The Thalessemias. In Molecular Basis of Blood Diseases. 2nd edition. Edited by Stamatoyannopoulos G, Nienhuis A, Majerus P. Philadelphia: W B Saunders Co; 1994.

38. Adams JG 3rd, Coleman MB: Structural hemoglobin variants that produce the phenotype of thalassemia. Semin Hematol 1990, 27:229-238.

39. Forget B, Pearson H: Hemoglobin Synthesis and the Thalassemias. In Blood: Principles and Practice of Hematology. Edited by Handin R, Lux S, Stoesel T. Philadelphia: JB Lippincott; 1995

40. Schwartz E, Benx E Jr: Thalassemia Syndromes. In Smith's Blood Diseases of Infancy and Childhood. 6th edition. Edited by Miller D, Baehner R. St Louis: CV Mosby; 1989:428.

41. Vento S, Cainelli F, Cesario F: Infections and thalassaemia. Lancet Infect Dis 2006, 6:226-233.

42. Rahav G, Volach V, Shapiro M, Rund D, Rachmilewitz EA, Goldfarb A: Severe infections in thalassaemic patients: prevalence and predisposing factors. Br J Haematol 2006, 133:667-674.

43. Vichinsky EP: The morbidity of bone disease in thalassemia. Ann N Y Acad Sci 1998, 850:344-348.

44. Voskaridou E, Terpos E, Spina G, Palermos J, Rahemtulla A, Loutradi A, Loukopoulos D: Pamidronate is an effective treatment for osteoporosis in patients with beta-thalassaemia. Br J Haematol 2003, 123:730-737.

45. Farmaki K, Angelopoulos N, Anagnostopoulos G, Gotsis E, Rombopoulos G, Tolis G: Effect of enhanced iron chelation therapy on glucose metabolism in patients with beta-thalassaemia major. Br J Haematol 2006, 134:438-444

46. Cunningham M, Sankaran V, Nathan D, Orkin S: The Thalassemias. In Nathan And Oski's Hematology Of Infancy And Childhood. 7th edition. Philadelphia: Saunders Elsevier; 2009

47. British Committee for Standards in Haematology Blood Transfusion Task Force: The administration of blood and blood components and the management of transfused patients. British Committee for Standards in Haematology, Blood Transfusion Task Force. Royal College of Nursing and the Royal College of Surgeons of England. Transfus Med 1999, 9:227-238.

48. Swanson K, Dwyre DM, Krochmal J, Raife TJ: Transfusion-related acute lung injury (TRALI): current clinical and pathophysiologic considerations. Lung 2006, 184:177-185

49. Cazzola M, De Stefano P, Ponchio L, Locatelli F, Beguin Y, Dessi C, Barella S, Cao A, Galanello R: Relationship between transfusion regimen and suppression of erythropoiesis in beta-thalassaemia major. Br $\mathrm{J}$ Haematol 1995, 89:473-478.

50. Royal College of Physicians of Edinburgh: Consensus statement on red cell transfusion. Transfus Med 1994, 4:177-178.

51. Goodnough LT, Brecher ME, Kanter MH, AuBuchon JP: Transfusion medicine. First of two parts-blood transfusion. N Engl J Med 1999 340:438-447.
52. Borgna-Pignatti $C$, Rugolotto $S$, De Stefano P, Zhao H, Cappellini MD, Del Vecchio GC, Romeo MA, Forni GL, Gamberini MR, Ghilardi R, Piga A, Cnaan A: Survival and complications in patients with thalassemia major treated with transfusion and deferoxamine. Haematologica 2004, 89:1187-1193.

53. Modell B, Khan M, Darlison M: Survival in beta-thalassaemia major in the UK: data from the UK Thalassaemia Register. Lancet 2000, 355:2051-2052.

54. Evangeli M, Mughal K, Porter JB: Which psychosocial factors are related to chelation adherence in thalassemia? A systematic review. Hemoglobin 2010, 34:305-321.

55. Andrews NC: Disorders of iron metabolism. N Engl J Med 1999, 341:1986-1995.

56. Gardenghi S, Marongiu MF, Ramos P, Guy E, Breda L, Chadburn A, Liu Y, Amariglio N, Rechavi G, Rachmilewitz EA, Breuer W, Cabantchik ZI, Wrighting DM, Andrews NC, de Sousa M, Giardina PJ, Grady RW, Rivella S: Ineffective erythropoiesis in beta-thalassemia is characterized by increased iron absorption mediated by down-regulation of hepcidin and up-regulation of ferroportin. Blood 2007, 109:5027-5035.

57. Kohgo $Y$, Ikuta K, Ohtake T, Torimoto $Y$, Kato J: Body iron metabolism and pathophysiology of iron overload. Int J Hematol 2008, 88:7-15.

58. Olivieri NF, Brittenham GM: Iron-chelating therapy and the treatment of thalassemia. Blood 1997, 89:739-761.

59. Morrison ED, Brandhagen DJ, Phatak PD, Barton JC, Krawitt EL, El-Serag HB, Gordon SC, Galan MV, Tung BY, loannou GN, Kowdley KV: Serum ferritin level predicts advanced hepatic fibrosis among U.S. patients with phenotypic hemochromatosis. Ann Intern Med 2003, 138:627-633.

60. Angelucci E, Brittenham GM, McLaren CE, Ripalti M, Baronciani D, Giardini C, Galimberti M, Polchi P, Lucarelli G: Hepatic iron concentration and total body iron stores in thalassemia major. N Engl J Med 2000, 343:327-331.

61. St Pierre TG, Clark PR, Chua-anusorn W, Fleming AJ, Jeffrey GP, Olynyk JK, Pootrakul P, Robins E, Lindeman R: Noninvasive measurement and imaging of liver iron concentrations using proton magnetic resonance. Blood 2005, 105:855-861.

62. Anderson $L$, Holden $S$, Davis B, Prescott $E$, Charrier CC, Bunce NH, Firmin DN, Wonke B, Porter J, Walker JM, Pennell DJ: Cardiovascular T2-star (T2*) magnetic resonance for the early diagnosis of myocardial iron overload. Eur Heart J 2001, 22:2171-2179.

63. Elalfy M, Shebl S, Badr M, Elsafy U, Salama M, Al-Tonbary Y, Abdel Rahman Y, Qari M, Al Damnhouri G, Al Hawsawi Z, Wali Y, Yesilipek M, Kilinc Y, Yazman D, Karakas Z, Tricta F: Frequency of Agranulocytosis and Mild Neutropenia During Deferiprone Therapy in Clinical Practice. ASH Annual Meeting 2012, 120:996.

64. Vermylen C: What is new in iron overload? Eur J Pediatr 2008, 167:377-381

65. Uygun V, Kurtoglu E: Iron-chelation therapy with oral chelators in patients with thalassemia major. Hematology 2013, 18:50-55.

66. Lucarelli G, Galimberti M, Polchi P, Angelucci E, Baronciani D, Giardini C, Politi P, Durazzi SM, Muretto P, Albertini F: Bone marrow transplantation in patients with thalassemia. N Engl J Med 1990, 322:417-421.

67. Lucarelli G, Galimberti M, Polchi P, Angelucci E, Baronciani D, Giardini C, Andreani M, Agostinelli F, Albertini F, Clift RA: Marrow transplantation in patients with thalassemia responsive to iron chelation therapy. $N$ Engl J Med 1993, 329:840-844.

68. Sodani P, Gaziev D, Polchi P, Erer B, Giardini C, Angelucci E, Baronciani D, Andreani M, Manna M, Nesci S, Lucarelli B, Clift RA, Lucarelli G: New approach for bone marrow transplantation in patients with class 3 thalassemia aged younger than 17 years. Blood 2004, 104:1201-1203.

69. Al-Jefri A, Ayas A, Al Musa A, Al Mahr M, Al Saleh M, Rifai S, Sabbah R, Al Seraihy A, Al Ahmari A, Khairy E, Al Hassan I, El Solh H: Allogeneic stem cell transplantation in patients with beta-thalassemia: King Faisal Specialist Hospital and Research Centre Experience. Hemoglobin 2009, 33(Suppl 1):S183-187.

70. Smiers FJ, Krishnamurti L, Lucarelli G: Hematopoietic stem cell transplantation for hemoglobinopathies: current practice and emerging trends. Pediatr Clin North Am 2010, 57:181-205.

71. Al Jefri AH: Advances in allogeneic stem cell transplantation for hemoglobinopathies. Hemoglobin 2011, 35:469-475.

72. Gaziev J, Sodani P, Lucarelli G, Polchi P, Marktel S, Paciaroni K, Marziali M, Isgro A, Simone MD, Roveda A, Montuoro A, Lanti A, Alfieri C, De Angelis G, Gallucci C, Ciceri F, Roncarolo MG: Second hematopoietic SCT in patients with thalassemia recurrence following rejection of the first graft. Bone Marrow Transplant 2008, 42:397-404. 
73. Lucarelli G, Gaziev J: Advances in the allogeneic transplantation for thalassemia. Blood Rev 2008, 22:53-63.

74. Bernardo ME, Piras E, Vacca A, Giorgiani G, Zecca M, Bertaina A, Pagliara D, Contoli B, Pinto RM, Caocci G, Mastronuzzi A, La Nasa G, Locatelli F: Allogeneic hematopoietic stem cell transplantation in thalassemia major: results of a reduced-toxicity conditioning regimen based on the use of treosulfan. Blood 2012, 120:473-476.

75. Li C, Wu X, Feng X, He Y, Liu H, Pei F, Liao J, He L, Shi L, Li N, Liu Q, Liu S, Chen G, Su Q, Ren Y, Wang Y, Tan W: A novel conditioning regimen improves outcomes in beta-thalassemia major patients using unrelated donor peripheral blood stem cell transplantation. Blood 2012, 120:3875-3881.

76. Locatelli F, Rocha V, Reed W, Bernaudin F, Ertem M, Grafakos S, Brichard B, Li X, Nagler A, Giorgiani G, Haut PR, Brochstein JA, Nugent DJ, Blatt J, Woodard P, Kurtzberg J, Rubin CM, Miniero R, Lutz P, Raja T, Roberts I, Will AM, Yaniv I, Vermylen C, Tannoia N, Garnier F, lonescu I, Walters MC, Lubin $\mathrm{BH}, \mathrm{Gluckman}$ E: Related umbilical cord blood transplantation in patients with thalassemia and sickle cell disease. Blood 2003, 101:2137-2143.

77. Alkindi S, Dennison D: Umbilical Cord Blood Banking and Transplantation: A short review. Sultan Qaboos Univ Med J 2011, 11:455-461.

78. Cianciulli P: Treatment of iron overload in thalassemia. Pediatr Endocrinol Rev 2008, 6(Suppl 1):208-213.

79. De Sanctis V: Growth and puberty and its management in thalassaemia. Horm Res 2002, 58(Suppl 1):72-79.

80. Low LC: Growth, puberty and endocrine function in beta-thalassaemia major. J Pediatr Endocrinol Metab 1997, 10:175-184.

81. Wonke B: Bone disease in beta-thalassaemia major. Br J Haematol 1998, 103:897-901.

82. Perera NJ, Lau NS, Mathews S, Waite C, Ho PJ, Caterson ID: Overview of endocrinopathies associated with beta-thalassaemia major. Intern Med $J$ 2010, 40:689-696.

83. Raiola G, Galati MC, De Sanctis V, Caruso Nicoletti M, Pintor C, De Simone M, Arcuri VM, Anastasi S: Growth and puberty in thalassemia major. J Pediatr Endocrinol Metab 2003, 16(Suppl 2):259-266.

84. Chatterjee R, Bajoria R: Osteopenia-osteoporosis syndrome in patients with thalassemia: understanding of type of bone disease and response to treatment. Hemoglobin 2009, 33(Suppl 1):S136-138.

85. De Sanctis V, Skordis N, Galati MC, Raiola G, Giovannini M, Candini G, Kaffe K, Savvides I, Christou S: Growth hormone and adrenal response to intramuscular glucagon test and its relationship to IGF-1 production and left ventricular ejection fraction in adult B-thalassemia major patients. Pediatr Endocrinol Rev 2011, 8(Suppl 2):290-294.

86. Bajoria R, Chatterjee R: Hypogonadotrophic hypogonadism and diminished gonadal reserve accounts for dysfunctional gametogenesis in thalassaemia patients with iron overload presenting with infertility. Hemoglobin 2011, 35:636-642.

87. Merchant RH, Shirodkar A, Ahmed J: Evaluation of growth, puberty and endocrine dysfunctions in relation to iron overload in multi transfused Indian thalassemia patients. Indian J Pediatr 2011, 78:679-683.

88. Chatterjee R, Mukhopadhyay TN, Chandra S, Bajoria R: Sex steroid priming for induction of puberty in thalassemia patients with pulsatile reversible hypogonadotrophic hypogonadism. Hemoglobin 2011, 35:659-664.

89. Eldor A, Rachmilewitz EA: The hypercoagulable state in thalassemia. Blood 2002, 99:36-43.

90. Barnett CF, Hsue PY, Machado RF: Pulmonary hypertension: an increasingly recognized complication of hereditary hemolytic anemias and HIV infection. JAMA 2008, 299:324-331.

91. Rasekhi AR, Naderifar M, Bagheri MH, Shahriari M, Foroutan H, Karimi M, Nabavizadeh SA: Radiofrequency ablation of the spleen in patients with thalassemia intermedia: a pilot study. Am J Roentgenol 2009, 192:1425-1429.

92. Machado NO, Grant CS, Alkindi S, Daar S, Al-Kindy N, Al Lamki Z, Ganguly SS: Splenectomy for haematological disorders: a single center study in 150 patients from Oman. Int J Surg 2009, 7:476-481.

93. ACOG Committee: ACOG Practice Bulletin. Clinical Management Guidelines for Obstetrician-Gynecologists Number 64, July 2005 (Replaces Committee Opinion Number 238, July 2000): hemoglobinpathies in pregnancy. Obstetrics and Gynecology 2005, 106:203-210.

94. Cogliandro T, Derchi G, Mancuso L, Mayer MC, Pannone B, Pepe A, Pili M, Bina P, Cianciulli P, De Sanctis V, Maggio A: Society for the Study of T,
Hemoglobinopathies: Guideline recommendations for heart complications in thalassemia major. J Cardiovasc Med (Hagerstown) 2008, 9:515-525.

95. Origa R, Piga A, Quarta G, Forni GL, Longo F, Melpignano A, Galanello R: Pregnancy and beta-thalassemia: an Italian multicenter experience. Haematologica 2010, 95:376-381.

96. Exjade product monograph USA 2011. http://www.drugs.com/monograph/ exjade.html.

97. Ferriprox product monograph. http://www.drugs.com/monograph/ deferiprone.html.

98. Deugnier Y, Turlin B, Ropert M, Cappellini MD, Porter JB, Giannone V, Zhang $Y$, Griffel L, Brissot P: Improvement in liver pathology of patients with beta-thalassemia treated with deferasirox for at least 3 years. Gastroenterology 2011, 141:e1201-1203. 1202-1211, 1211.

99. Patel $\mathrm{H}$, Qari M, Mousa S: Iron Balance in $\beta$-thalassemia: Maintaining an Oxidant/Antioxidant Ratio. J App Hematol 2012, 3:4-11.

100. Cappellini M-D, Cohen A, Eleftheriou A, Piga A, Porter J, Taher A: Guidelines for the clinical management of thalassemia. 2nd edition. Nicosia, Cyprus: Thalassemia International Federation; 2008.

101. Mahachoklertwattana $P$, Sirikulchayanonta V, Chuansumrit A, Karnsombat $P$, Choubtum L, Sriphrapradang A, Domrongkitchaiporn S, Sirisriro R, Rajatanavin R: Bone histomorphometry in children and adolescents with beta-thalassemia disease: iron-associated focal osteomalacia. J Clin Endocrinol Metab 2003, 88:3966-3972.

102. Tsay J, Yang Z, Ross FP, Cunningham-Rundles S, Lin H, Coleman R, Mayer-Kuckuk P, Doty SB, Grady RW, Giardina PJ, Boskey AL, Vogiatzi MG: Bone loss caused by iron overload in a murine model: importance of oxidative stress. Blood 2010, 116:2582-2589.

103. Lasco A, Morabito N, Gaudio A, Buemi M, Wasniewska M, Frisina N: Effects of hormonal replacement therapy on bone metabolism in young adults with beta-thalassemia major. Osteoporos Int 2001, 12:570-575.

104. Taksande A, Prabhu S, Venkatesh S: Cardiovascular aspect of Betathalassaemia. Cardiovasc Hematol Agents Med Chem 2012, 10:25-30.

105. Borgna Pignatti C, Carnelli V, Caruso V, Dore F, De Mattia D, Di Palma A, Di Gregorio F, Romeo MA, Longhi R, Mangiagli A, Melevendi C, Pizzarelli G, Musumeci S: Thromboembolic events in beta thalassemia major: an Italian multicenter study. Acta Haematol 1998, 99:76-79.

106. Cogliandro T, Derchi G, Mancuso L, Mayer MC, Pannone B, Pepe A, Pili M, Bina $P$, Cianciulli $P$, De Sanctis V, Maggio A: Guideline recommendations for heart complications in thalassemia major. J Cardiovasc Med (Hagerstown) 2008, 9:515-525.

107. Maggio A, Filosa A, Vitrano A, Aloj G, Kattamis A, Ceci A, Fucharoen S, Cianciulli P, Grady RW, Prossomariti L, Porter JB, lacono A, Cappellini MD, Bonifazi F, Cassara F, Harmatz P, Wood J, Gluud C: Iron chelation therapy in thalassemia major: a systematic review with meta-analyses of 1520 patients included on randomized clinical trials. Blood Cells Mol Dis 2011, 47:166-175.

108. Modell B, Khan M, Darlison M, Westwood MA, Ingram D, Pennell DJ: Improved survival of thalassaemia major in the UK and relation to $\mathrm{T}^{*}{ }^{*}$ cardiovascular magnetic resonance. J Cardiovasc Magn Reson 2008, 10:42.

109. Bourli E, Dimitriadou M, Economou M, Vlachaki E, Christoforidis A, Maratou E, Stanopoulos I, Argyropoulou P, Aivazis V: Restrictive pulmonary dysfunction and its predictors in young patients with beta-thalassaemia major. Pediatr Pulmonol 2012, 47:801-807.

110. Morris CR, Vichinsky EP: Pulmonary hypertension in thalassemia. Ann N Y Acad Sci 2010, 1202:205-213.

111. Chueamuangphan N, Wongtheptien W, Nawarawong W, Sukornthasarn A, Chuncharunee S, Tawichasri C, Patumanond J: Clinical indicators for pulmonary arterial hypertension in thalassemia. J Med Assoc Thai 2012, 95:16-21.

112. Aydinok Y, Erermis S, Bukusoglu N, Yilmaz D, Solak U: Psychosocial implications of Thalassemia Major. Pediatr Int 2005, 47:84-89.

113. Aydin B, Yaprak I, Akarsu D, Okten N, Ulgen M: Psychosocial aspects and psychiatric disorders in children with thalassemia major. Acta Paediatr Jpn 1997, 39:354-357.

114. Pakbaz Z, Treadwell M, Yamashita R, Quirolo K, Foote D, Quill L, Singer T, Vichinsky EP: Quality of life in patients with thalassemia intermedia compared to thalassemia major. Ann N Y Acad Sci 2005, 1054:457-461.

115. Guideline: Alternative approaches to the treatment of thalassemia. http://www.ithanet.eu/ithapedia/index.php/Guideline: Alternative_approaches_to_the_treatment_of_thalassemia.

116. Wang $\mathrm{H}$ : Prediction, validation and targeted interference of erythroid regulatory modules. In Dissertation. University Park, PA, USA: The Pennsylvania State University, Eberly College of Science; 2006. 
117. Alhamdan NA, Almazrou YY, Alswaidi FM, Choudhry AJ: Premarital screening for thalassemia and sickle cell disease in Saudi Arabia. Genet Med 2007, 9:372-377.

118. Kuliev A, Rechitsky S, Verlinsky O, Ivakhnenko V, Evsikov S, Wolf G, Angastiniotis M, Georghiou D, Kukharenko V, Strom C, Verlinsky Y: Preimplantation diagnosis of thalassemias. J Assist Reprod Genet 1998, 15:219-225

doi:10.1186/1750-1172-8-143

Cite this article as: Qari et al.: Regional consensus opinion for the management of Beta thalassemia major in the Arabian Gulf area. Orphanet Journal of Rare Diseases 2013 8:143.

\section{Submit your next manuscript to BioMed Central and take full advantage of:}

- Convenient online submission

- Thorough peer review

- No space constraints or color figure charges

- Immediate publication on acceptance

- Inclusion in PubMed, CAS, Scopus and Google Scholar

- Research which is freely available for redistribution 